\title{
Sustainable Development and Rural Tourism in Lithuania
}

\author{
Romantè Bučienè \\ Vilniaus kolegija/University of Applied Sciences \\ r.buciene@ekf.viko.1t \\ Jūrate Merkienè \\ Vilniaus kolegija/University of Applied Sciences \\ j.merkiene@ekf.viko.lt
}

Recibido: 10-04-2014

Aceptado: 26-05-2014

\begin{abstract}
Keywords: sustainability; rural tourism; socially responsible personality; communication skills.
\end{abstract}

\section{ABSTRACT}

The article deals with the importance of sustainable development and rural tourism in Lithuania. The issues concerning the establishing and maintaining of a homestead in a rural environment are reviewed. Communication skills, business planning and language skills are of utmost importance in the flourishing of rural tourism in Lithuania. The future world of business has to change if we are to overcome the crises in society and in the personality. The social responsibility of educational institutions is high on the agenda. Business companies have to be socially responsible and eco-friendly particularly what concerns rural tourism.
Palabras clave: sostenibilidad; el turismo rural; Socialmente Responsable de la personalidad; capacidad de comunicación.

\section{RESUMEN}

El artículo habla de la importancia del desarrollo sostenible y el turismo rural en Lituania. Los asuntos relacionados con la el establecimiento y mantenimiento de una granja en el medio rural son propiedad hasta. Las habilidades de comunicación, la planificación empresarial y conocimientos de idiomas son de suma importancia en el florecimiento del turismo rural en Lituania. El futuro del mundo de los negocios tiene que cambiar si queremos superar la crisis en la sociedad y en la personalidad. La responsabilidad social de las instituciones educativas es una prioridad en la agenda. Empresas de negocios tienen que ser socialmente responsable y respetuoso del medio ambiente Particularmente lo que preocupa a turismo rural. 


\section{INTRODUCTION}

Sustainable development has been defined in many ways, but the most frequently quoted definition is from "Our Common Future", also known as the Brundtland Report (1987, p. 43):

'Sustainable development is development that meets the needs of the present without compromising the ability of future generations to meet their own needs. It contains within it two key concepts:

\footnotetext{
the concept of 'needs', in particular the essential needs of the world's poor, to which overriding priority should be given; and

- the idea of limitations imposed by the state of technology and social organization on the environment's ability to meet present and future needs.'
}

All definitions of sustainable development require that we see the world as a system where space and time are included. Thinking of the world as a system over space, it can be understood that air pollution from Asia affects air quality in Europe, and that pesticides sprayed in Sweden could harm wild life on the coast of Lithuania. Thinking of the world as a system over time, it is easy start to realize that the decisions our ancestors made about how to farm the land continue to affect agricultural practice today. In addition to that the economic policies endorsed today will have an impact on the future world.

In addition to the above mentioned quality of life is a system, too. It is an advantage to be physically healthy, but what if you are poor and not eligible to education? Having a secure income is convenient, but what if the air in that part of the world is unclean? The concept of sustainable development is rooted in this sort of systems thinking. It helps us understand ourselves and our world. The problems we face are complex and serious but they need to be addressed.

\section{THE CONCEPT OF SUSTAINABLE DEVELOPMENT}

Sustainable development is a principle stating the relevance for human life. The most important issue of which is a desirable future state for human societies in which living conditions and the use of resources meet human needs without undermining the sustainability of natural systems and the environment, so that future generations may also have their needs met.

Sustainable development ties together concern for the capacity of natural systems with the social, political, and economic challenges faced by humanity. The United Nations Millennium Declaration identified principles and treaties on sustainable development, including economic development, social development and environmental protection. On 8 September 2000, following a three day Millennium Summit of world leaders at the headquarters of the United Nations, the General Assembly adopted the Millennium Declaration. A follow-up outcome of the resolution was passed by the General Assembly on 14 December 2000 to guide its implementation.

The Millennium Declaration key objectives were adopted by 189 world leaders during the summit: The Declaration stresses the observance of international human rights law and international humanitarian law under the Principles of United Nations Charter as well as the treaties on sustainable development. The most important values and principles are stated as Freedom, Equality, Solidarity, Tolerance, Respect for nature - 'Shown in the management of all living species and natural resources, in accordance with the precepts of sustainable development, shared responsibility, protecting our common environment'. 
The UN uses these principles Ecological modernization, Environmentalism, Human impact on the environment, Stewardship, Sustainable development to execute the values which can be applied in numerous fields including Eco-village, Education for Sustainable Development etc.

An issue important to the future development of Lithuania concerning sustainable development is the development of rural tourism.

\section{THE CONCEPT OF RURAL TOURISM}

The concept of rural tourism has a noble cause, and in actual fact is another kind of sustainable tourism that exploits resources in rural regions, causes little or no harmful impact, and generates increasing benefits to rural areas in terms of rural productivity, employment, improved distribution of wealth, conservation of the rural environment and culture, local people's involvement, and a suitable way of adapting traditional beliefs and values to modern times.

Rural tourism is beneficial for both rural and urban society. In order to foster the socio-cultural and economic development in rural areas, tourism could help in boosting the local performing arts, conserving the local culture, and hopefully preventing migration. A problem which is very relevant in Lithuania. The youth of rural areas seem to be attracted either to the city life in Lithuania or most often another EU country.

Thus rural tourism could attract tourists by providing excellent glimpse of the village ambience with local cuisine. The tourism topics which could be distinguished as the most important are the following: natural tourism, cultural tourism, health tourism and ecotourism.

Natural tourism, which is mainly aimed for recreation having little or no ecological impact on the environment, includes a wide range of activities: swimming, canoeing, fishing, horse riding etc. Services of the above mentioned natural tourism are popular in Lithuania. However the business is involved in only one or two services and most often exists separately from the rural tourism business. In Lithuania there is a tendency to provide pony riding, fishing etc. However the number of young families due to migration is decreasing and for the rural tourism business it is not profitable to keep ponies all year the round.

It is clear that rural natural tourism is attractive for the tourist but attention should be paid to elderly residents, foreigners, students and pupils. A well trained guide could be of extremely big help to all those taking part in such an event encouraging the enjoyment of a pollution free environment and lots of greenery.

Cultural tourism, which is concerned with the culture and history of local people, could play a bigger role in rural tourism which in its turn could work more with the municipalities of the region, the Ministry of Culture to promote events, festivals taking place in the region. It must be pointed out that it is being done but there is room for improvement. As always promoting is both rural tourism and cultural events in a more pronounced or interesting form would be a great help to the business and to the customer. There should be a programme organized for the tourist to encourage rural tourism.

Health tourism, which is concerned with health and beauty treatments could be a good option for rural tourism. Many people are suffering from various physical and mental illness like stress, loss of sleep, mental tension, and obesity. In Lithuania in some rural tourism sites it is possible to enjoy the spa procedures. Of course arranging such a service could be costly and would not to be affordable for every rural tourism business. Offering spa and even if there is a necessity yoga or using local peat for treatment of visitors at the rural tourism venue could be an option for the rural tourism entrepreneurs. 
Ecotourism, which is a responsible type of tourism, preserves natural resources maintaining the well-being and social values of the local community. The guest of a rural tourism site would without any doubt visit the local forest, have the opportunity to pick berries, mushrooms, admire the natural beauty of a bird sanctuary, lake or waterway etc. The owner or the employee of the company would by all means offer tourists necessary knowledge to guide them because the guests expect to learn something. As the President of the Lithuanian Rural Tourism Association admitted at an interview the educational development of young and old alike would enhance the creating of a better and more ecologically minded society.

Rural tourism is considered to be not only an excursion to the country-side or the leisure time spent in a rural homestead and all the services offered to the client. This includes all the services, the culture, natural environment, traditions and the introduction to historical topics. Demand for accommodation often can be upgraded to meet tourist requirements. Rural ambience may be natural or created to provide a rural lifestyle.

\section{FINANCIAL SUPPORT}

Financial support is and will always remain an important tool enabling the viability and competition of rural tourism to flourish.

In 2013 there were 620 rural homesteads offering their services. This accounts for an increase of 2.5 per cent of homesteads and an increase in the number places. The majority of rural homesteads may be found in Ignalina, Klaipèda, Molètai, Trakai, Utena. Without doubt holiday-makers opt for accommodation near lakes and rivers.

Rural tourism can boast of a decade or more of investments in Lithuania. It is clear that the economic responsibility of a company is by far the most fundamental and important. Every company has to make a profit, produce goods or services.

It would seem that the time has come for the businesspeople to start counting the profit. However the profitability indexes are rather low. regions

Table 1. Holiday-makers, number of nights of rural tourism homesteads according to

\begin{tabular}{|c|c|c|c|c|c|c|c|}
\hline \multirow{3}{*}{ Regions } & \multirow{2}{*}{\multicolumn{2}{|c|}{$\begin{array}{l}\text { Number of holiday- } \\
\text { makers in } \\
\text { thousands }\end{array}$}} & \multirow{3}{*}{$\begin{array}{l}\begin{array}{l}\text { Number of } \\
\text { nights in } \\
\text { thousands }\end{array} \\
20122013\end{array}$} & \multicolumn{2}{|c|}{$\begin{array}{l}\text { Comparison of previous year, } \\
\text { increase, decrease(-), per cent }\end{array}$} & \multirow{2}{*}{\multicolumn{2}{|c|}{$\begin{array}{l}\text { Average } \\
\text { number of } \\
\text { holiday- } \\
\text { maker nights }\end{array}$}} \\
\hline & & & & \multirow{2}{*}{\begin{tabular}{|l} 
Number of \\
holiday-makers \\
2012
\end{tabular}} & \multirow[t]{2}{*}{$\begin{array}{l}\text { Number of } \\
\text { nights }\end{array}$} & & \\
\hline & 2012 & 2013 & & & & 2012 & 2013 \\
\hline Total & 260,7 & 275,8 & $475,7525,8$ & 5,8 & 10,5 & 1,82 & 1,91 \\
\hline Alytaus & 41,8 & 41,5 & $70,3 \quad 72,4$ & $-0,7$ & 3,1 & 1,68 & 1,75 \\
\hline Kaunas & 45,7 & 49,7 & \begin{tabular}{|l|l|}
76,6 & 84,7
\end{tabular} & 9,0 & 10,6 & 1,68 & 1,70 \\
\hline Klaipèda & 17,5 & 20,5 & \begin{tabular}{|l|l|}
32,4 & 38,6 \\
\end{tabular} & 17,4 & 19,1 & 1,86 & 1,88 \\
\hline Marijampolè & é & 9,8 & $20,3 \quad 22,2$ & 5,5 & 9,1 & 2,18 & 2,25 \\
\hline Panevėžys & 12,9 & 14,0 & 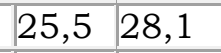 & 8,7 & 10,3 & 1,98 & 2,01 \\
\hline Šiauliai & 8,4 & 8,9 & $13,6 \quad 15,0$ & 6,5 & 9,7 & 1,63 & 1,68 \\
\hline Tauragè & 4,5 & 4,9 & $12,8 \quad 14,0$ & 8,7 & 9,5 & 2,81 & 2,83 \\
\hline Telšiai & 15,2 & 15,5 & $21,7 \quad 23,7$ & 2,0 & 9,2 & 1,43 & 1,53 \\
\hline Utena & 41,9 & 47,6 & \begin{tabular}{|l|l|}
87,7 & 101,7
\end{tabular} & 13,4 & 15,9 & 2,09 & 2,14 \\
\hline Vilnius & 63,6 & 63,3 & $114,7125,4$ & $-0,5$ & 9,3 & 1,81 & 1,98 \\
\hline
\end{tabular}

Source: Official Statistics Portal (2014). Tourism. Vilnius, Statistics Lithuania. 
Observing the tables from the Lithuanian Board of Statistics it can be noted that the biggest number of holiday-makers in 2012 were in Kaunas, the second biggest town in Lithuania. Taurage was on the bottom of the list. The same distribution continues to be observed in 2013. The capital city of Lithuania is on the lead concerning the number of nights with Taurage remaining last on the list.

Comparing the number of holiday-makers an increase in percentage concerning Klaipeda - a town on the Baltic coast may be observed and Alytus - a town in the centre of Lithuania can only reveal the lowest percentage. The average number of holiday-maker nights increased slightly from 1,82 to 1,91 .

There seems to be a slight increase in all the above positions. However there is room for improvement in all the above listed regions.

Table 2. Rural tourism homesteads and number of places according to region

\begin{tabular}{l|l|l|l|l|l|l|}
\hline \multirow{2}{*}{ Regions } & Number of rural homesteads & \multicolumn{2}{l}{ Number of rooms } & \multicolumn{2}{l|}{ Number of beds } \\
\cline { 2 - 8 } & 2012 & 2013 & 2012 & 2013 & 2012 & 2013 \\
\hline Total & 605 & 620 & 4212 & 4537 & 13087 & 13648 \\
\hline & & & & & & \\
\hline Alytus & 96 & 88 & 644 & 588 & 2131 & 2021 \\
\hline Kaunas & 67 & 68 & 539 & 625 & 1792 & 1909 \\
\hline Klaipëda & 39 & 56 & 255 & 363 & 769 & 1117 \\
\hline Marijampolë & 24 & 22 & 158 & 168 & 651 & 603 \\
\hline Panevëpys & 23 & 26 & 210 & 224 & 634 & 686 \\
\hline Siauliai & 17 & 15 & 140 & 143 & 457 & 407 \\
\hline Tauragė & 15 & 15 & 119 & 119 & 277 & 277 \\
\hline Telšiai & 37 & 36 & 287 & 292 & 813 & 806 \\
\hline Utena & 175 & 184 & 779 & 981 & 2390 & 2687 \\
\hline Vilnius & 112 & 110 & 1081 & 1034 & 3173 & 3135 \\
\hline
\end{tabular}

Source: Official Statistics Portal (2014). Tourism. Vilnius, Statistics Lithuania.

Reviewing Table 2 it can be observed that the biggest number of rural homesteads may be found in Utena with the capital city Vilnius coming second place. Tauragë in the west of Lithuania remains on the bottom of the list. Looking at the number of rooms Vilnius boasts of the biggest number with Tauragë remaining stable in its lowest position. According to the number of beds Vilnius and Utena are in close competition and as can be observed Tauragë is in the last position on the list.

It is clear why Vilnius the capital city is in the leading position. Utena its closest rival boasts of a short distance from the capital, a popular beer factory and lots of hardworking employees. Tauragë has a beautiful untouched beauty, authenticity but is not off the highway, too far away from the bigger cities, neighbouring regions like Điauliai or Klaipëda could compete but the level of service and the variety of services should be far wider.

According to the Rural Development Department of the Ministry of Agriculture during the previous period from 2007-2013 a total sum of 40 million out of the 46 million of financial support were allocated for the development of rural tourism.

Those who received financial support for rural tourism were returned 50-65 percent and more of investment funds from the project. More than 75 percent of the sum is returned when the support is allocated for the developing of certified national heritage. The President of the Lithuanian Rural Tourism Association observed that the support of the Rural Development Programme for 2007-2013 was an opportunity for entrepreneurs to set up 
rural tourism homesteads, expand the services. The use of the EU funds for this field is by far much better than in our neighbouring countries like Estonia and Poland. The Ministry of Agriculture could be a good example to others especially, the Ministry of Economy which should pay more attention to rural tourism and view it as its sector.

The Economist (2014, p. 60) notes: 'Consumer tastes seem to be diverging. On the one hand, there is a growing preference for authenticity, uniqueness, personal enrichment, deep cultural context, and a sense of environmental and social responsibility in leisure experiences writes Hector Medina of Alvarez \& Marsal, a professional-services firm, in a recent report'.

The most important issue for rural tourism in Lithuania is to develop more services and increase their quality.

Currently those businesspeople who do have a desire to establish their own rural homestead have the possibility to do so, but only with their own capital. If the homestead is a success only then is it possible to apply for support from the EU. This has been a lesson learnt for many beginners who with support from the EU, started a business but were soon ceased due to the fact that the strengths, weaknesses, threats were not properly foreseen to the full.

The notion of creating win-win outcomes through corporate socially responsible activities has been raised before. Peter Drucker (1984, p. 62) argues '...the proper "social responsibility" of a business is to tame the dragon, that is to turn a social problem into economic opportunity and economic benefit, into productive capacity, into human competence, into well-paid jobs, and into wealth'.

The price of rural tourism is high, requiring lots of effort, depending on the economic situation of the country and in addition on human factors. If there is no devotion, love and understanding of the current client, if it does not fit the taste of the travelling and broadminded, the holiday-maker with an acquired taste there is no future for rural tourism business. The more so, that there will not be any additional funding from the EU for homesteads for the period of 2014-2020.

Socially responsible employees, managers, stakeholders should understand that every corporation needs to have a win-win perspective and should be aimed at satisfying stakeholders' demands while, at the same time, allowing the firm to pursue its operations and be ahead in the market with the legal, ethic and discretionary aspects of a company.

Lithuania can boast of 620 farmsteads. However the average occupancy of cottages just 30 percent. It is necessary to raise the bar for quality services, reducing seasonality, increasing the number of overnight stays. The farmsteads with a vision and an aim would be able to apply for financial support from the EU, which is so vital for the business. The intended financial support is foreseen at 532 million Lt which has not been confirmed by the EU Commission yet.

Previously books were the source of ideas and contemplation. Currently, this has moved to a more virtual reality. However sometimes it is necessary to escape from it and enjoy nature at its best. Nevertheless the question of the vast amount of information has not made us better or more socially responsible but only more stressed. Being lost in an overwhelming amount of data, the developing member of society is the one who has a demand for the guru's, teacher's, guide's helping hand. The rural homestead could become a centre not only of recreation, to rest the body and the soul but an educational centre teaching and involving holiday-makers to bake bread, make jam, weave material, collect herbs, milk a cow and ride a horse, provide clients with specialized services, offering the service of spa. Or simply, if possible to increase accommodation to a maximum of 55 rooms which is eligible according to the legislation and regulations of Lithuania. 


\section{CHALLANGES IN RURAL TOURISM}

There are other specialists who doubt the fact that rural tourism farmsteads could afford to perform major maintenance repairs, upgrading courses, purchase inventory, commence to offer specialized service etc.

These pursuits could be enjoyed both by the young and the elderly residents both from towns and cities. If a close contact were to remain with the clients the services provided could be enhanced by additional occupation. The idea of rural tourism is to be connected with the past, the history of Lithuania, yet to present provide Lithuanians, Europeans and other guests with a chance to eat and drink authentic food of Lithuania, commune with nature and enjoy vigorous outdoor events which are characteristic to the region.

The never ending issue on encouraging our residents, guests from different countries, students - our future members of society to live and think in a world of today but to take inspiration from the countryside and rural tourism from history in order to become an active member of society. There is always a need to encourage people to delve much deeper into the inner soul, to learn to think about a much deeper meaning of living in a society. It is important to understand the connection between the urban and rural, between the body and the soul and to harmoniously develop yin and yan energy in each of our souls.

The problems which rural tourism faces are quite a few. Most homesteads plan to employ more employees. This is usually unrealistic because the average number recruited is twice as low. The reason for such a difference in numbers is that the sector is usually a family business. Another red-tape issue - the possibility of enjoying breakfast, what would seem the only logical way of promoting the rural area, its cuisine. The State Food and Veterinary Service is working hard and keeping the standards of food high. However the situation in rural tourism homesteads seems to hinder the innovative processes.

The number of Rural Tourism Homesteads - only 11 with five storks, meaning the highest category in its area. This is an enormous setback for many of the other rural tourism homesteads. The public institutions which follow the procedures concerning following the requirements for premises personnel and resources are looking for better ways of solving the problem. This would encourage entrepreneurship and be acceptable for the State Food and Veterinary Service.

All the homesteads belonging to the association members according to the service level and living conditions are labelled by a stork (as star hotels) - from 1 to 5 , the more storks the more comfort they promise. At present, 70 per cent of homesteads have been labelled with a 3, 4 and 5 stork status. According to specialists, tourists do not opt only for a bed and an outdoor toilet, the lowest category of 1 or 2 stork marked farms. The stork is a national bird of Lithuania. According to ancient traditions the stork was the guardian of people from a very early stage in life.

Country houses are already available in the world for tourists in perhaps the world's most popular accommodation website www.booking.com. Owners should brush up their communication, language and other soft skills to attract and promote their businesses.

Certainly that is not the only field which should be of concern. Even more important area is expanding the meaning of the word homestead - offering not only bed and breakfast but also an educational programme. For those rural residents and owners who are beginners in the area of rural tourism marketing, business, languages and other necessary subjects could be taught by professionals.

Another issue concerning rural tourism in Lithuania is the lack of authenticity: ecological farms, domestic animals, olden trades. Homesteads - simply for the busy family 
from a city, to live in peace and solitude, for at least a week. The majority of the homesteads are leased for celebrations - parties, receptions etc. A disadvantage is the difficulty in finding the place of destination. No signs, no guidelines or directions on the internet. Thinking in a broad sense and being strategically minded information should be available and it should be conveyed in many languages which the owners of a homestead could use for the benefit of their business.

There are numerous examples of rural tourism homesteads offering saunas, bicycles, Nordic walking poles, sport grounds, ponies - a wide range for the most various tastes.

Some homestead owners observe that motels and illegal places for a stay overnight are competing with them. In order to be a profitable rural homestead the owners are forced to lease the rooms for parties which are noisy and not always the concept of sustainable rural tourism is recognised as such.

Other owners of rural homesteads complain that guests prefer to have all the service directly from garden to table. There is no interest in ecology, sustainable farming. To educate the future guest in a new and innovative way of thinking will take time. The benefit of involving students in different projects connected with ecology, sustainability may make a change in the fashion of guests visiting and enjoying the service of rural tourism and sustainable development.

Educational institutions need to change their tone more than their syllabuses. According to Schumpeter (2009) 'the original sin of business schools is boosterism. Business schools need to make more room for people to prick business bubbles, expose management fads. Kings once employed jesters to bring them down to earth. It's time for business schools to do likewise'.

A socially responsible and business minded personality should have knowledge and study well. The skills acquired at college should be applied in the future work place in society. For the younger generation it still remains an enormous challenge to apply their skills with the aim of becoming a socially responsible citizen and to earn a living as a businessperson.

An issue of course in the rural tourism field will be the ability to speak more foreign languages. The owners and staff of rural tourism businesses should upgrade their skills to communicate with the guests otherwise they will not be getting much benefit from rural tourism.

Business planning skills are also important for any entrepreneur. They require technical knowledge and the ability to organize and run a company. Advertisement and sales promotion will play a very important role in creating awareness of the provided services of rural tourism.

And another essential and important issue is communication. The ability to communicate effectively is a soft skill learnt and acquired through experience. Much of the success of the rural tourism business will depend on the owner's ability to be warm, professional and understanding.

Volunteer work is a very good example how young people can learn to use their skills, expand their network of friends and acquaintances and learn from one another to be socially active and gain basic business skills. Students carrying out volunteer work at rural tourism sites could serve as a boost of energy for all parties included.

Retraining or upgrading courses, projects, exchange programmes could help rural tourism business owners shed away their fears and gain self-confidence, a positive attitude which in its turn radiates out to guests encouraging them to be active, enthusiastic and curious customers. 
Rural tourism can bring various benefits such as foreign exchange, employment, higher government revenues and the transformation of agriculture into a modern service industry.

Every society should foresee and already foresees the negative effects of environmental hazards or stressful situations. In order to redirect those feelings, time spent in a rural tourism milieu will be extremely beneficial. The impact of rural environment can improve the state of body and mind. The natural habitats, bio-diversity historical monuments will be observed.

Many other institutions, ministries, associations and organizations could serve to open the doors to a new bigger world for many more members of our society, people from abroad to help become socially responsible personalities in an eco-friendly community by enjoying the urban landscape with all its advantages. How should the dots be connected? An educated college student or local resident goes to the countryside, establishes a rural tourism homestead, with support from an association or government organization, constantly offers new services to guests from Lithuania or abroad.

Rural tourism can bring various benefits such as foreign exchange, employment, higher government revenues and the transformation of agriculture into a modern service industry.

A reduction in migration, a market for agricultural products and handicrafts will develop in rural areas. The scenic beauty, historical importance may appeal to city dwellers caught up in today's fast pace of lifestyle.

The major challenges are a need to preserve the environment and natural resources, education, proper understanding for both tourists and local people.

Governments should recognize the importance of rural tourism as a priority and help in creating a healthy competitive business environment, try to generate data for decisionmaking bodies investing in the developing of human resources, create a suitable infrastructure.

Rural tourism can help in creating sustainable development in Lithuania - a small but beautiful country with 6 thousand lakes, forests and, so much more to see. When are you coming?

\section{CONCLUSIONS}

The concept of rural tourism and sustainability are discussed. The challenges which rural homestead owners face in Lithuania should be addressed on a wider basis.

The main goal of the rural tourism business - the successful sale and improvement of quality of services and a consistent development of the range of services and perfecting of quality.

Lithuania has to develop sustainable rural tourism, promote ecotourism, foster the expansion of water tourism opportunities, and promote cycling, walking and car tourism routes.

Educational institutions could cooperate more with rural tourism companies offering their services not only as employees but also as voluntary workers.

A socially responsible businessperson will bring benefit to the company and society making it more eco-friendly. Expanding the range of services and promoting rural tourism more vigorously, Lithuania could be more appealing to domestic and foreign guests. 
The state authorities should pay more attention to the rural tourism development, use modern technologies and information tools aimed at furthering the collaboration with neighbouring countries.

Lithuanian rural tourism is a viable and attractive investment, receptive to new ideas and knowledge, and sector-specific EU support in producing positive results.

\section{REFERENCES}

AHT International-Agrisystems-Consortium (2003): Vidutinès trukmés SAPARD įvertinimas Lietuvos Respublikoje, http://www.nma.lt/uploads/files/dir20/dir1/17_0.php.

Astromskienè, Adelè (1999): "Kaimo turizmas - poilsio paslaugu sistema", Organizaciju vadyba: sisteminiai tyrimai, 12: 7-14.

Astromskienè, Adelè (2009): "Vadybiniai kaimo turizmo verslo raidos Lietuvoje aspektai" [Managerial aspects of rural tourism business development in Lithuania], Vadybos mokslas ir studijos - kaimo verslu ir ju infrastruktūros plètrai, 19(4): 14-20.

Crane, Andrew; McWilliams, Abagail; Matten, Dirk; Moon, Jeremy, and Siegel, Donald S. (Editors) (2008): The Oxford Handbook of Corporate Social Responsibility, New York, Oxford University Press.

Dapkus, Rimantas (2008): "Kultūrinio turizmo plètros perspektyvos", Vadybos mokslas ir studijos - kaimo verslu ir ju infrastruktūros plètrai, 15(4): 29-40.

Drucker, Peter F. (1984): "The New Meaning of Corporate Social Responsibility", California Management Review, 26(2): 53-63.

Gerber, Michael E. (2006): The E-Myth Revisited: Why Most Small Businesses Don't Work and What to Do About It, New York, HarperCollins.

Hall, Derek R.; Kirkpatrick, Irene, and Mitchell, Morag (2005): Rural Tourism and Sustainable Business, New York.

Lietuvos Respublikos turizmo îstatymas, Nr. VIII-667, Valstybės žinios, Nr. 32-852, 199804-03.

Official Statistics Portal (2014). Tourism. Vilnius, Statistics Lithuania, http:/ / osp.stat.gov.lt/en/statistiniu-rodikliu-analize?id=2477\&status=A.

Schumpeter, Joseph A. (2009): "The Pedagogy of the Privileged", The Economist, September 26: 72 .

"The return of the free lunch" (2014): The Economist, May 31: 60.

Tolle, Eckhart (2004): The Power of Now, Novato, New World Library.

United Nations Millennium Declaration (2000), 8th plenary meeting, 8 September, http://www.un.org/millennium/declaration/ares552e.htm.

Visser, Wayne; Matten, Dirk; Manfred, Pohl, and Tolhurst, Nick (Editors) (2010): The A to $Z$ of Corporate Social Responsibility, Chichester, John Wiley \& Sons.

Vitkienè, Elena (2001): "Visuomenès rekreacija kaip socialinis-ekonominis reiškinys", Tiltai, 3(16): 99-107.

World Commission on Environment and Development (1987): Our Common Future, Oxford: Oxford University Press.

\section{HOW TO CITE THIS ARTICLE IN BIBLIOGRAPHIES}

Bučienė, R. y Merkienė, J. (2014): "Sustainable Development and Rural Tourism in Lithuan", Rotur. Revista de Ocio y Turismo, 7: 10-19, ISSN-e: 2695-6357, DOI: https:// doi.org/10.17979/rotur.2014.7.1.1283 